\title{
Positron Emission Tomography Imaging Demonstrates Correlation between Behavioral Recovery and Correction of Dopamine Neurotransmission after Gene Therapy
}

\author{
Ludovic Leriche, ${ }^{1,2 *}$ Tomas Björklund, ${ }^{3 *}$ Nathalie Breysse, ${ }^{3 *}$ Laurent Besret, ${ }^{1,2}$ Marie-Claude Grégoire, ${ }^{1,2}$ \\ Thomas Carlsson, ${ }^{3}$ Frédéric Dollé, ${ }^{4}$ Ronald J. Mandel, ${ }^{5}$ Nicole Déglon, ${ }^{1,2}$ Philippe Hantraye, ${ }^{1,2 *}$ and Deniz Kirik ${ }^{3,6 *}$ \\ ${ }^{1}$ Centre National de la Recherche Scientifique, Unité de Recherche Associée 2210, 91401 Orsay, France, ${ }^{2}$ Commissariat à l'Énergie Atomique (CEA), Biomedical \\ Imaging Institute, Molecular Imaging Research Center, 92265 Fontenay-aux-Roses, France, ${ }^{3}$ Brain Repair and Imaging in Neural Systems, Department of \\ Experimental Medical Science, Lund University, SE-221 84, Lund, Sweden, ${ }^{4} \mathrm{CEA}$, Biomedical Imaging Institute, Service Hospitalier Frédéric Joliot, 91406 Orsay, France, \\ ${ }_{5}^{5}$ Department of Neuroscience, McKnight Brain Institute and Gene Therapy Centre, College of Medicine, University of Florida, Gainesville, Florida 32610, and ${ }^{\circ}$ Lund University \\ Bio-Imaging Center, Faculty of Medicine, SE-221 84 Lund, Sweden
}

In vivo gene transfer using viral vectors is an emerging therapy for neurodegenerative diseases with a clinical impact recently demonstrated in Parkinson's disease patients. Recombinant adeno-associated viral (rAAV) vectors, in particular, provide an excellent tool for long-term expression of therapeutic genes in the brain. Here we used the [ $\left.{ }^{11} \mathrm{C}\right]$ raclopride $[(S)-(-)-3,5$-dichloro- $N$-((1-ethyl-2-pyrrolidinyl)methyl)-2-hydroxy6-methoxybenzamide] micro-positron emission tomography (PET) technique to demonstrate that delivery of the tyrosine hydroxylase (TH) and GTP cyclohydrolase 1 (GCH1) enzymes using an rAAV5 vector normalizes the increased $\left[{ }^{11} \mathrm{C}\right]$ raclopride binding in hemiparkinsonian rats. Importantly, we show in vivo by microPET imaging and postmortem by classical binding assays performed in the very same animals that the changes in $\left[{ }^{11} \mathrm{C}\right]$ raclopride after viral vector-based enzyme replacement therapy is attributable to a decrease in the affinity of the tracer binding to the $\mathrm{D}_{2}$ receptors, providing evidence for reconstitution of a functional pool of endogenous dopamine in the striatum. Moreover, the extent of the normalization in this non-invasive imaging measure was highly correlated with the functional recovery in motor behavior. The PET imaging protocol used in this study is fully adaptable to humans and thus can serve as an in vivo imaging technique to follow $\mathrm{TH}+\mathrm{GCH} 1$ gene therapy in $\mathrm{PD}$ patients and provide an additional objective measure to a potential clinical trial using rAAV vectors to deliver L-3,4-dihydroxyphenylanaline in the brain.

Key words: Parkinson's disease; recombinant adeno-associated viral vector; tyrosine hydroxylase; GTP cyclohydrolase-1; positron emission tomography; molecular imaging; compartmental modeling

\section{Introduction}

Parkinson's disease (PD) is the second most common age-related neurological disorder, affecting $\sim 1 \%$ of people over 65 years old and $4-5 \%$ of people over 85 , and thus is considered as a major

Received Sept. 19, 2008; revised Nov. 29, 2008; accepted Dec. 16, 2008.

This work was supported by Swedish Research Council Grants K2005-33IT-15332-1A and K2005-33X-14552 03A, NeuroNE Network of Excellence Program of the European Union Grant LSHM-CT-2004-512039, the Fondation pour la Recherche Médicale, and the Commissariat à I'Energie Atomique. N.B. was a postdoctoral fellow supported by the Marie-Curie Training Program of the European Union. We thank Prof. Philip Seeman (University of Toronto, Toronto, Ontario, (anada) for expert opinions in setting up the in vitro $\mathrm{D}_{2}$ binding assay and Anneli Josefsson and Ulla Jarl for excellent technical support.

*L.L., T.B., N.B., P.H., and D.K. contributed equally to this work.

Correspondence should be addressed to Dr. Deniz Kirik, Department of Experimental Medical Science, Brain Repair and Imaging in Neural Systems, Lund University, BMC D11, SE-221 84, Lund, Sweden. E-mail: deniz.kirik@med.lu.se.

L. Leriche's present address: Centre de Recherche Pierre Fabre, 17 avenue Jean-Moulin, 81106 Castres Cedex, France. N. Breysse's present address: Wyeth Pharmaceuticals, 865 Ridge Road, Monmouth Junction, Princeton, NJ 08852.

L. Besret's present address: Sanofi-Aventis, Oncologie, Magendie seine, 13 quai Jules Guesde, 94403 Vitry sur Seine Cedex, France.

M.-C. Grégoire's present address: Radiopharmaceutical Research Institute, Australian Nuclear Science and Technology Organisation, Lucas Heights, Menai, New South Wales 2234, Australia.

T. Carlsson's present address: Experimental Neurology Unit, Department of Neurology, Phillips University, Hans Meerwein Strasse, 35043 Marburg, Germany.

DOI:10.1523/JNEUROSCI.4491-08.2009

Copyright $\odot 2009$ Society for Neuroscience $\quad$ 0270-6474/09/291544-10\$15.00/0 social health problem with significant economic impact (Tanner and Goldman, 1996; Lindgren et al., 2005; Dorsey et al., 2007). The disease is characterized by a progressive loss of dopamine (DA)producing neurons in the midbrain, which results in a decline of DA innervation of the major forebrain terminal field, the striatum (Kish et al., 1988; Fearnley and Lees, 1991). The typical motor features of $\mathrm{PD}$ are resting tremor, rigidity, akinesia/bradykinesia, and postural instability/gait disturbance, which usually develop over many years as the disease progresses. Pharmacological dopamine replacement using oral L-3,4-dihydroxyphenylalanine (L-DOPA) has been the treatment of choice since its introduction in 1967 (Cotzias et al., 1967). However, even if the symptomatic benefits of this medication are remarkable in the early stages of the disease, with time the majority of PD patients develop motor complications beginning with wearing off and then progressing to marked swings between immobility and mobility (on-off motor fluctuations), involuntary movements (dyskinesia), and neuropsychiatric complications (Marsden and Parkes, 1976; Obeso et al., 2000).

Therefore, considerable efforts have been made to develop novel treatment approaches that provide antiparkinsonian benefits without side effects. Continuous systemic delivery of L-DOPA or DA agonists have been shown to efficiently avoid complications of oral L-DOPA medication (Quinn et al., 1984; 
Kurlan et al., 1986; Obeso et al., 1986; Mouradian et al., 1987) (for review, see Olanow et al., 2006). In this context, direct viral vector-mediated transfer of enzymes responsible for DA synthesis in the brain is currently being explored as a novel therapeutic strategy (Carlsson et al., 2007). One approach is based on the coexpression of tyrosine hydroxylase (TH) and GTP cyclohydrolase 1 (GCH1) genes in the DA denervated striatum using recombinant adeno-associated viral (rAAV5) vectors. Local striatal DOPA synthesis provided in this way results in a robust behavioral recovery and reversal of dyskinetic side effects produced by the chronic oral administration of L-DOPA (Mandel et al., 1998; Kirik et al., 2002; Carlsson et al., 2005). The efficacy of this gene therapy approach has been assumed to result from the de novo synthesis of DA in the parkinsonian striatum by the residual aromatic L-amino acid decarboxylase (AADC) enzyme present in serotonin terminals, glial cells, and striatal neurons. However, the direct demonstration that an endogenous functional DA pool can be efficiently restored after $\mathrm{AAV}$-mediated gene therapy has not been achieved yet.

The $\left[{ }^{11} \mathrm{C}\right]$ raclopride $[(S)-(-)-3,5$-dichloro- $N$-( (1-ethyl-2pyrrolidinyl)methyl)-2-hydroxy-6-methoxybenzamide] positron emission tomography (PET) technique has been used to assess, in an indirect manner, the alterations in DA neurotransmission in the brain. Raclopride is a mixed $D_{2} / D_{3}$ antagonist with similar affinity as DA for this type of receptor. In the intact brain, the endogenous ligand (i.e., DA) and $\left[{ }^{11} \mathrm{C}\right]$ raclopride compete to occupy the postsynaptic receptor sites located on striatal neurons, yielding a signal proportional to $\left[{ }^{11} \mathrm{C}\right]$ raclopride specifically bound to the receptors (Farde et al., 1985). Meanwhile, $\left[{ }^{11} \mathrm{C}\right]$ raclopride signal has been shown to be increased above normal values in the PD patients (Antonini et al., 1997). Such an increase in $\left[{ }^{11} \mathrm{C}\right]$ raclopride binding can be attributed to either a loss of endogenous neurotransmitter providing an indirect measure of DA levels at the postsynaptic receptor sites or, alternatively, to a denervation-induced postsynaptic change in receptor density (Lee et al., 1978).

We developed and used a new, single experiment, the $\left[{ }^{11} \mathrm{C}\right] \mathrm{ra}-$ clopride quantification method, to separately assess changes in binding affinity and $\mathrm{D}_{2}$ receptor density after gene transfer in parkinsonian animals. Here we show that increased $\left[{ }^{11} \mathrm{C}\right]$ raclopride signal in the DA-depleted striatum is essentially attributable to an increased affinity of $\left[{ }^{11} \mathrm{C}\right]$ raclopride binding to the $\mathrm{D}_{2}$ receptors and that the gene therapy mediated by rAAV5-TH and rAAV5-GCH1 vectors reverses these changes, thus providing unequivocal evidence that a functional pool of DA is reestablished after gene transfer. Importantly, these in vivo observations were also confirmed in the very same animals after PET imaging after extraction of their striata and separate measurement of $\mathrm{D}_{2}$ receptor binding parameters by conventional in vitro binding assays. The two methods show that the extent of the restoration in the $\left[{ }^{11} \mathrm{C}\right]$ raclopride binding affinity is well correlated with the amount of DA synthesized by the viral vectors as well as the recovery in spontaneous motor behaviors.

\section{Materials and Methods}

\section{Subjects and surgical procedures}

Forty-eight male Sprague Dawley rats were purchased from Harlan and were housed two to three per cage with ad libitum access to food and water under a $12 \mathrm{~h}$ light/dark cycle. Surgery for 6-hydroxydopamine (6-OHDA) lesion and vector injections were performed under isoflurane anesthesia using a $5 \mu \mathrm{l}$ Hamilton syringe fitted with a glass capillary (outer diameter, 60-80 $\mu \mathrm{m}$ ) attached to a stereotaxic frame (Stoelting). Housing and all experimental procedures performed in these experiments were performed according to the regulations set by the Ethical
Committee for Use of Laboratory Animals in the Lund-Malmö region, the European Ethical Committee (86/609 EEC), and French legislation (2001/464).

\section{Experimental design}

A total of 37 animals were injected with 6-OHDA in the right medial forebrain bundle (MFB) to remove the ascending dopaminergic system unilaterally. Thirty-one animals fulfilled the inclusion criteria (more than six full body turns per minute after injection of $2.5 \mathrm{mg} / \mathrm{kg}$ $d$-amphetamine, and $<20 \%$ left paw use in the cylinder test) and were allocated into three groups. The first group of animals received injection of a 1:1 mixture of rAAV5-TH and rAAV5-GCH1 vectors $(n=9)$. The second group received an rAAV5 vector encoding for the marker green fluorescent protein (rAAV5-GFP; $n=6$ ) and served as vector-injected controls. The third group of animals served as lesion-only controls ( $n=$ $10)$. A fourth group of normal controls $(n=11)$ were included in the imaging study. Finally, six additional lesioned animals were injected with either TH + CGH1 or the GFP genes and were used for histological analysis to demonstrate transgene expression in the brain. The cylinder test was repeated at 12 weeks after transduction to confirm the functional recovery in the therapeutic vector group $(\mathrm{TH}+\mathrm{GCH} 1)$ and the maintenance of stable deficits in the control animals. Four to 7 months after transduction, rats underwent $\left[{ }^{11} \mathrm{C}\right]$ raclopride PET scans. At 39 weeks after transduction, a final battery of behavioral tests were performed, and all the animals included in the imaging study were then killed by decapitation, their brains were frozen in isopentane, and each of their striata were dissected out separately for in vitro binding assay and tissue catecholamine measurements using HPLC. The additional vector injected rats $(n=6)$ were perfused with $4 \%$ paraformaldehyde and processed for histological analysis.

\section{Lesion of the ascending dopaminergic system}

Animals received two injections of 8.75 and $7 \mu \mathrm{g}$ of 6-OHDA $(3.5 \mu \mathrm{g} / \mu \mathrm{l})$ aimed at targeting the MFB unilaterally on the right side. The injections were made at the following coordinates as calculated relative to bregma according to the stereotaxic atlas of Paxinos and Watson (1986): anterior, -3.8 and $-4.4 \mathrm{~mm}$; lateral, -1.6 and $-1.4 \mathrm{~mm}$. The ventral positions for the two injection sites were -7.8 and $-8.0 \mathrm{~mm}$ below the dural surface, respectively, and the tooth bar was set at $-3.9 \mathrm{~mm}$. The 6-OHDA solution was infused at a rate of $1 \mu \mathrm{l} / \mathrm{min}$, and the needle was left in the tissue for an additional $3 \mathrm{~min}$ period before it was slowly retracted.

\section{Production and intracerebral administration of viral vectors}

The vectors used in this study were provided by the University of Florida Vector Core. All rAAV5 vectors (rAAV5-TH, rAAV5-GCH1, and rAAV5-GFP) were driven by a hybrid promoter consisting of an enhancer element from the cytomegalovirus promoter and the chicken $\beta$-globin intron (Xu et al., 2001). Vectors were produced by a cotransfection of HEK 293 cells with transfer plasmid coding for the transgene and inverted terminal repeats from AAV2 and helper plasmids coding for the genes necessary for production and packaging of AAV2 genome into AAV5 capsids as described previously (Grimm et al., 2003). The cell lysate was purified by a discontinuous iodixanol gradient and ionexchange chromatography using HiTrap Sepharose Q columns (GE Healthcare), followed by concentration using Apollo protein concentrators (Orbital Biosciences) after which the buffer was exchanged to lactated Ringer's solution (Apoteksbolaget). Final titers, as determined using dot-blot analysis, were $1.2 \times 10^{13}, 1.0 \times 10^{13}$, and $3.2 \times 10^{13}$ genome copies/ml for the rAAV5-TH, rAAV5-GCH1, and rAAV5-GFP vectors, respectively.

Animals in the rAAV5-GFP vector control group received a total of 4 $\mu \mathrm{l}$ of the vector stock. The rAAV5-TH + rAAV5-GCH1-treated group was injected with $4 \mu \mathrm{l}$ of a 1:1 mix of the two vector stocks. The vector injections were distributed over two deposits at the following coordinates with reference to bregma: anterior, +1.0 and $0.0 \mathrm{~mm}$; lateral, -2.8 and $-3.4 \mathrm{~mm}$. Two $1 \mu \mathrm{l}$ deposits were delivered in each tract at -4.8 and $-3.8 \mathrm{~mm}$ below the dural surface. All injections were made at a rate of 1 $\mu \mathrm{l} / \mathrm{min}$. At the end of the second injection, the glass capillary was left in place for an additional $3 \mathrm{~min}$ period before it was slowly retrieved. 


\section{Behavioral tests}

Amphetamine- and apomorphine-induced rotation. Four weeks after the 6-OHDA lesions (before viral vector injections), amphetamine-induced rotational behavior was monitored to select animals with profound dopaminergic lesions. After an injection of $2.5 \mathrm{mg} / \mathrm{kg} d$-amphetamine (Apoteksbolaget), right and left full body turns were monitored over 90 min using automated rotometer bowls. The data were expressed as net full body turns per minute ipsilateral to the lesion. Only animals that exhibited more than six turns per minute were included in the study. One month after the completion of the last PET scan, apomorphine (SigmaAldrich) and amphetamine-induced rotational behavior were conducted on all animals. In these experiments, $30 \mathrm{~min}$ after administration of apomorphine $(0.5 \mathrm{mg} / \mathrm{kg})$ or $d$-amphetamine $(2.5 \mathrm{mg} / \mathrm{kg})$, the rats were placed in Plexiglas bowls for a 5 min period of habituation. Full body turns were counted during the following 5 min period by examiners blinded to the treatment.

Cylinder test. Spontaneous forelimb use in the cylinder test was assessed as described previously (Kirik et al., 2000; Schallert et al., 2000). This test is designed to score spontaneous weight-shifting movements initiated by the forelimb as they moved freely in a 20 -cm-diameter cylinder without handling by the experimenter. Contacts made by each forepaw with the wall of the cylinder were scored from videotape by an observer blinded to the identity of the animals. The data are presented as left (impaired) paw use as percentage of the total number of touches, in which an unbiased animal would receive a score of $50 \%$. Performance in the cylinder test was monitored once at 2 weeks before the viral vector injections, a second time at 12 weeks after the viral vector injections, and a third time after the PET imaging experiment was completed (i.e., 39 weeks after viral transduction).

\section{microPET scanning and data processing}

$\left[{ }^{11} \mathrm{C}\right]$ raclopride was labeled with carbon-11 on its methylether function from the corresponding desmethyl phenolic precursor $[(S)-(-)-3,5-$ dichloro- $N$-((1-ethyl-2-pyrrolidinyl)methyl)-2,6-dihydroxy-benzamide] and the highly efficient methylating reagent $\left[{ }^{11} \mathrm{C}\right]$ methyl triflate (Langer et al., 1999). Typically, $2.96-5.55 \mathrm{GBq}$ of $\left[{ }^{11} \mathrm{C}\right]$ raclopride (radiochemical and chemical purity of $95 \%$ ) was obtained in routine within $40-45 \mathrm{~min}$ of radiosynthesis with specific radioactivities ranging from 18.5 to $55.5 \mathrm{GBq} /$ $\mathrm{mmol}$. The total amount (mass) of $\left[{ }^{11} \mathrm{C}\right]$ raclopride injected was either obtained using the natural decay of the carbon-11 (half-life of $20.4 \mathrm{~min}$ ) or by adjustment to the desired value $(4.74 \pm 0.82 \mathrm{nmol})$ by addition of unlabeled raclopride to the radiotracer syringe.

Rats were scanned on a dedicated small animal PET scanner (NeuroFocus 220; Concorde Microsystems). Before scanning, the left femoral vein was cannulated for ligand injection. For scanning, the animals were placed within the scanner using a dedicated stereotactic head holder in prone position under isoflurane anesthesia $\left(1.5 \mathrm{~L} / \mathrm{min} \mathrm{O}_{2}\right.$ and air containing $2 \%$ isoflurane). To decrease the amount of $\left[{ }^{11} \mathrm{C}\right]$ raclopride metabolized during the study, we used a selective histamine $\mathrm{H}_{2}$ receptor antagonist and a cytochrome $\mathrm{P} 450$ inhibitor, cimetidine $(150 \mathrm{mg} / \mathrm{kg}$, i.p., $30 \mathrm{~min}$ before $\left[{ }^{11} \mathrm{C}\right]$ raclopride injection). A $10 \mathrm{~min}$ transmission scan was first performed with an external ${ }^{68} \mathrm{Ge}$ point source. Then, a bolus injection of $\left[{ }^{11} \mathrm{C}\right]$ raclopride $(37-100 \mathrm{MBq} ; 4.74 \pm 0.82 \mathrm{nmol})$ was given intravenously via the femoral vein cannula and scanning commenced. Dynamic emission scans were acquired in list-mode format over $60 \mathrm{~min}$. The acquired data were then sorted into 14 timeframes [0-12 min divided in 2 min frames (six frames), 12-60 min divided in $6 \mathrm{~min}$ frames (eight frames)]. Each sinogram was normalized, corrected, and reconstructed with a twodimensional Fourier rebinning and ordered-subsets expectation maximization (FORE-OSEM) algorithm ( 16 subsets, 4 iterations). Regions of interests (ROIs) were delineated using an anatomo-functional image processing software (Anatomist; http://www.brainvisa.info). All striatal ROIs were drawn using the same volume $\left(20 \mathrm{~mm}^{3}\right)$, and cerebellar volumes $(69.6 \pm 16.0$ $\mathrm{mm}^{3}$ ) were kept within anatomical landmarks. Kinetics were then calculated and expressed as picomoles per milliliter.

\section{$\left[{ }^{11}\right.$ C]Raclopride PET kinetics analysis}

Based on previous multi-injection modeling studies with $\left[{ }^{11} \mathrm{C}\right]$ raclopride in rats (Mauger et al., 2005) as well as previous in-house modeling studies (Delforge et al., 1993, 1995), we developed and validated a new modeling approach based on a partial saturation model, more adapted to the microPET and allowing the determination of both $B_{\max }$ and $K_{d} V_{r}$ using a single-experiment protocol (see supplemental Technical Annex, available at www.jneurosci.org as supplemental material). Using this new method, $\mathrm{D}_{2}$ receptor density and affinity can be estimated for each striatal ROI using a nonlinear fit of the bound ligand versus free ligand concentrations. Briefly, the mass of injected ligand was calculated such as to occupy at least $75 \%$ of the receptors (partial saturation model), so that a dynamic "Scatchard-like equilibrium" could occur within a validated time range. In our previous modeling studies designed to fully characterize and quantify $\left[{ }^{11} \mathrm{C}\right]$ raclopride-specific binding in the living rat (Mauger et al., 2005) (simulation studies shown in supplemental Technical Annex, available at www.jneurosci.org as supplemental material), we had identified and estimated all the parameters of the underlying nonlinear compartmental model and validated that the cerebellum could serve as a region of reference for free and nonspecific striatal binding. Based on these results, simulation studies allowed us to validate that, using a range of injected mass between 4.5 and $5.0 \mathrm{nmol}$, a Scatchard like-equilibrium state occurs between 12 and $50 \mathrm{~min}$ after tracer injection (see supplemental Technical Annex, available at www.jneurosci.org as supplemental material). At these times, $\mathrm{D}_{2}$-receptor apparent density $B_{\max }$ and affinity $K_{d} V_{r}$ can be estimated for each striatal ROI using a nonlinear fit of the bound ligand (B) versus free ligand $(\mathrm{F})$ concentration: $\mathrm{B}=\left(\mathrm{F} \times B_{\max }\right) /\left(\mathrm{F}+K_{d} V_{r}\right)$.

\section{Postmortem analysis}

The rats were deeply anesthetized with isoflurane $\left(5 \%\right.$; flow rate $\mathrm{O}_{2}, 2-3$ $\mathrm{L} / \mathrm{min}$ ) and killed by decapitation after at least 2 weeks from any pharmacological manipulation. The brains were rapidly removed and cut into two pieces at the level of the hypothalamus. The forebrain was immediately frozen in 2-methyl-butane $\left(-30^{\circ} \mathrm{C}\right)$ and stored at $-80^{\circ} \mathrm{C}$ until use. The midbrain-hindbrain was postfixed in ice-cold, $4 \%$ paraformaldehyde in $0.1 \mathrm{M}$ phosphate buffer, $\mathrm{pH} 7.4$, for $24 \mathrm{~h}$ at $4^{\circ} \mathrm{C}$ and then kept in $25 \%$ sucrose for $24 \mathrm{~h}$ before additional processing. At the time of analysis, the striatal tissue was dissected from the rest of the forebrain at subzero temperature, weighed, and stored on dry ice. Thereafter, the striatal tissue was homogenized by ultrasonic disintegrator on ice in $\mathrm{D}_{2}$ assay buffer (in mM: 50 Tris- $\mathrm{HCl}, 1 \mathrm{EDTA}, 5 \mathrm{KCl}, 1.5 \mathrm{CaCl}_{2}, 4 \mathrm{MgCl}_{2}$, and $120 \mathrm{NaCl}$, $\mathrm{pH}$ 7.4). One hundred microliters of the homogenate was then pipetted into $133 \mu \mathrm{l}$ of $0.8 \mathrm{~mm}$ perchloric acid for HPLC measurements as described below.

The fixed brain tissue was cut into $35 \mu \mathrm{m}$ coronal sections on a semiautomated freezing microtome (Microm HM 450), collected into six series, and stored in antifreeze solution $(0.5 \mathrm{M}$ sodium phosphate buffer, $30 \%$ glycerol, and $30 \%$ ethylene glycol) at $-20^{\circ} \mathrm{C}$ until additional processing. Immunohistochemistry was performed using antibodies raised against TH (rabbit IgG, 1:10,000; Pel-Freez), GCH1 (rabbit IgG, 1:5000; custom made for R. Mandel), and neuronal-specific nuclear protein (NeuN) (MAB 377, 1:100 mouse monoclonal IgG; Millipore). The staining was visualized using the avidin-biotin peroxidase method (ABC Elite; Vector Laboratories) developed by 3,3'-diaminobenzidine in $0.01 \% \mathrm{H}_{2} \mathrm{O}_{2}$ color reaction.

In vitro $\mathrm{D}_{2}$ receptor binding assay. The in vitro $\mathrm{D}_{2}$ receptor binding assay was conducted on each separate striata of all PET-imaged animals based on a modified version of the in vitro $\mathrm{D}_{2}$ binding assay described previously by Seeman et al. (1992). The tissue homogenate (prepared as above) was diluted with $10 \mathrm{ml}$ of ice-cold assay buffer (final concentration, $4 \mathrm{mg}$ tissue $/ \mathrm{ml}$ ), vortexed, and divided into 48 samples of $200 \mu \mathrm{l}$. To determine the nonbound raclopride and raclopride bound to nonspecific saturable sites, $100 \mu \mathrm{l}$ of $200 \mathrm{~mm}$ haloperidol was added to half of the samples, whereas the remaining samples received the same amount of assay buffer. The samples were incubated for $30 \mathrm{~min}$, and then $\left[{ }^{3} \mathrm{H}\right] \mathrm{ra}-$ clopride was added to triplicates in increasing amounts, resulting in a final concentration between $125 \mathrm{pm}$ and $16 \mathrm{~nm}$. The samples were then incubated for $2 \mathrm{~h}$ at room temperature before centrifugation at 14,000 $\mathrm{rpm}$ for $15 \mathrm{~min}$. The pellet was then washed, and the tip of the Eppendorf tube with pellet was cut off into LSC mixture (Ultima Gold; PerkinElmer Life and Analytical Sciences) and vortexed, and, $24 \mathrm{~h}$ later, the number of 

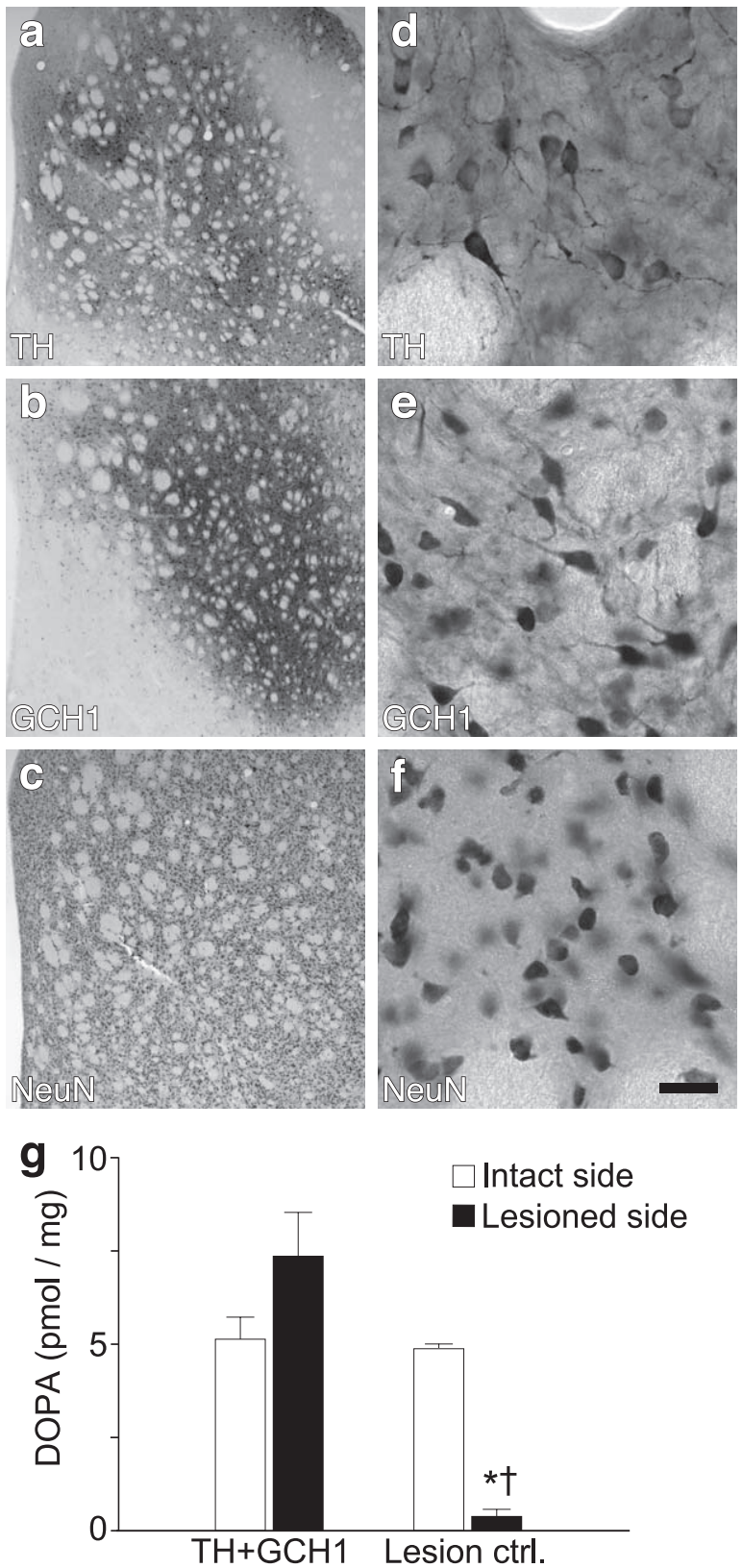

Figure 1. Striatal gene transfer of TH and GCH1 genes using rAAV5 vectors. The efficiency of the rAAV5-TH vector was assessed by immunohistochemical staining of sections with antibodies against TH $(\boldsymbol{a}, \boldsymbol{d})$ and $\mathrm{GCH} 1(\boldsymbol{b}, \boldsymbol{e})$ proteins as well as the NeuN neuronal marker $(\boldsymbol{c}, \boldsymbol{f}) . \boldsymbol{d}$-f are high-power views from the same sections as illustrated in $\boldsymbol{a}-\boldsymbol{c}$, respectively. TH staining shows a widespread expression of the transgenic human TH protein, in which numerous cell bodies and their dendritic projections are filled in the dorsal striatum (d). $\mathrm{GCH} 1$ expression is visualized using an antibody that specifically recognized the human $\mathrm{GCH} 1$ protein $(\boldsymbol{b}, \boldsymbol{e})$. Nonspecific effects of transduction was assessed by NeuN staining, which indicated that there were no apparent toxicity of striatal neurons on the injected side of the brain $(\boldsymbol{c}, \boldsymbol{f})$. Coexpression of TH and $\mathrm{GCH} 1$ proteins restored the in vivo DOPA synthesis capacity to normal levels in the lesioned striatum $(\boldsymbol{g}) .{ }^{*}$ indicates different from the intact side; $†$ indicates different from the respective lesion side from the TH $+\mathrm{GCH} 1$ group. Kruskal-Wallis nonparametric test, $\chi_{(3,19)}^{2}=12.23$, $p<0.01$, followed by post hoc comparisons using Mann-Whitney $U$ test with Bonferroni's correction. Scale bar: $\boldsymbol{a}-\boldsymbol{c}, 500 \mu \mathrm{m} ; \boldsymbol{d}-\boldsymbol{f}, 25 \mu \mathrm{m}$.

decays per minute was determined using a liquid scintillation counter (Beckman LS 6500; Beckman Coulter), which was quantified using an external standard calibration curve. The final data was plotted as a Scatchard plot, and $B_{\max }, K_{d}$, and binding potential (BP) were calculated.

HPLC analysis of monoamines. The tissue homogenate was centrifuged (10 min at $10,000 \mathrm{rpm}$ at $4^{\circ} \mathrm{C}$ ), after which the supernatant was filtered through minispin filters for an additional $3 \mathrm{~min}$ at 10,000 rpm. The tissue extracts were analyzed by HPLC-electrochemical detection for DA, 5-HT, and their metabolites. Twenty-five microliters of each sample were injected by a cooled autosampler (Spark Holland Midas) into an electrochemical detector (guard cell ESA 5020, glass-carbon electrode analytical cell ESA 5011 coupled to a ESA Coulochem III). A reverse-phase C18 column was used for compound separation ( $3 \mu \mathrm{m}$ ReproSil-pur, $4.6 \mathrm{~mm}$ inner diameter, $150 \mathrm{~mm}$ length; Chrompack). The mobile phase $(5 \mathrm{~g} / \mathrm{L}$ sodium acetate, $30 \mathrm{mg} / \mathrm{L} \mathrm{Na}_{2}$-EDTA, $100 \mathrm{mg} / \mathrm{L}$ octane-sulfonic acid, and $9 \%$ methanol, $\mathrm{pH} 4.2$ ) was delivered at a flow rate of $500 \mu \mathrm{l} / \mathrm{min}$. Peak identification and quantification was conducted using the Clarity Chromatographic software package (DataApex).

\section{Statistical analysis}

All statistics were conducted using the SPSS 15 statistical package (SPSS). The between-groups differences of neurotransmitter concentrations in Figures 1 and 4 were calculated using nonparametric statistics because the data failed the criteria of equal variance and normal distribution required in parametric statistics (floor effect in the lesion and control vector groups). Here a Kruskal-Wallis one-way test was followed by Mann-Whitney U post hoc test in which the significances were estimated by Monte Carlo simulation and by use of the "Exact" module, respectively. Correlations in Figures 3-5 were estimated using the Pearson's product-moment correlation coefficient with two-tailed significance presented. Two-way ANOVA tests performed on data presented in Figures 3 and 4 were analyzed using the generalized linear model and the Wald $\chi^{2}$ to estimate the goodness of fit with Bonferroni's-corrected post hoc analysis.

\section{Results}

\section{rAAV5 vectors provide robust transgene expression and restores DOPA synthesis in the striatum}

rAAV5 vectors encoding human TH and GCH1 or the GFP genes were injected in the rat striatum at two sites. The efficiency of the transduction was evaluated by both histological and biochemical assays. Immunohistochemistry showed a robust and widespread expression of the human TH in the 6-OHDA lesioned striata that are deprived of the intrinsic TH-positive innervation (Fig. 1a,d). Similar distribution of viral vector-mediated expression of the human GCH1 was observed (Fig. 1b,e). Injection of the vectors did not have any detectable toxic effects on neurons in the striatum as evidenced by normal distribution of NeuN-positive cells in the injected area (Fig. 1c,f) and numbers of NeuN-positive neurons in the entire striatum as determined by stereological quantification methods (intact side, 2,953,016 \pm 302,630; injected side, 2,985,593 $\pm 151,698$ cells). The total number of THexpressing striatal cells was estimated to be $352,518 \pm 82,279$, representing on average $\sim 12.0 \%$ of the NeuN-positive neurons in the striatum.

Striatal TH enzyme activity was estimated by administering a centrally acting AADC inhibitor [NSD-1015 (3-hydroxybenzylhydrazine), $100 \mathrm{mg} / \mathrm{kg}]$. This treatment results in accumulation of newly synthesized DOPA that would otherwise be converted to DA by the AADC enzyme, and thus tissue DOPA levels can be used as measure of in vivo activity of the TH enzyme. Under these conditions, $\sim 5 \mathrm{pmol}$ of DOPA accumulated in the normal striatum within a $30 \mathrm{~min}$ time period, whereas the capacity to synthesize DOPA was severely impaired as a result of loss of intrinsic DA neurons in 6-OHDA lesioned side. In the rAAV5-TH + rAAV5-GCH1-treated animals, conversely, the DOPA synthesis capacity was significantly improved and restored to normal levels (Fig. $1 g$ ). This was associated with an increase in striatal $\mathrm{TH}$ protein in the animals from $6.0 \pm 1.5 \%$ in the lesion controls to $18.3 \pm 3.4 \%$ of the control side levels $(p<0.05$, Mann-Whitney $U$ test). 
Striatal rAAV5-TH and rAAV5-GCH1 delivery restores synaptic dopamine to normal levels in the parkinsonian brain The three-dimensional images and the quantitative measurements of apparent $B_{\max }$ and in vivo affinity (i.e., $K_{d} V_{r}$ ) were generated from time-activity curves obtained from $\left[{ }^{11} \mathrm{C}\right]$ raclopride micro-PET scans. As expected, unilateral 6-OHDA lesioning resulted in an increase in the $\left[{ }^{11} \mathrm{C}\right]$ raclopride binding on the lesioned side (right hemisphere) (Fig. 2b,c, arrowhead), whereas the contralateral side remained unchanged (Fig. 2, compare $b$ with a). Therapeutic vector delivery resulted in a complete reversal of the lesion-induced increase in $\left[{ }^{11} \mathrm{C}\right]$ raclopride binding (Fig. $2 c$ ) and normalized binding to values equivalent to those obtained on the intact side. Quantitative estimations of change in $\left[{ }^{11} \mathrm{C}\right]$ raclopride binding (Fig. $2 d$ ) were obtained by calculating the BP as defined by the ratio between $B_{\max }$ and $K_{d} V_{r}$.

To provide evidence that rAAV5mediated continuous DOPA delivery restores a functional pool of endogenous DA, we used a new quantification method based on a single PET scan to determine the apparent affinity of binding to the $\mathrm{D}_{2}$ receptors and the apparent receptor density in the striatum using a partial saturation protocol (Fig. 3a,c). This method is based on the ability of $\left[{ }^{11} \mathrm{C}\right]$ raclopride to reach a "dynamic equilibrium phase" (during which the equilibrium equations are still valid) between 12 and 50 min after an injection of this radiotracer that aims at occupying a large fraction of the $\mathrm{D}_{2}$ receptors available in the region of interest (at least $75 \%$ of them). Figure $3, a$ and $c$, illustrates that, within this timeframe after radiotracer injection, the relationship between the bound to free versus bound concentrations of $\left[{ }^{11} \mathrm{C}\right]$ raclopride becomes linear (Scatchard-like equilibrium state), allowing direct calculation of apparent $B_{\max }$ (by extrapolation of the linear fit to the $x$-axis) and $1 / K_{d} V_{r}$ (represented by the slope of the linear fit). Figure $3 e-g$ illustrates the specifically bound $\left[{ }^{11} \mathrm{C}\right]$ raclopride signal in the striatum over the dynamic equilibrium (12-50 min) imaging period expressed as either binding potential (Fig. 3e), apparent $B_{\max }$ (Fig. 3f), or apparent $K_{d} V_{r}$ (Fig. 3g). The in vivo apparent $K_{d} V_{r}$ and the $B_{\max }$ were calculated for each animal's striatum separately, as illustrated for one representative animal in each experimental group (Fig. $3 a, c$, solid lines for lesioned animals, dashed lines for intact controls). The average apparent $B_{\max }$ value in the intact striatum was $32.83 \pm 2.14$ (left side of the normal control animals), which was not modified by the lesion or the vector treatment (two-way ANOVA, $\chi_{(5,51)}^{2}=5.16 ; p=0.40$ ) (Fig. $3 f$ ). In contrast, the in vivo apparent affinity $\left(K_{d} V_{r}\right)$ for $\left[{ }^{11} \mathrm{C}\right]$ raclopride was significantly increased in the denervated striatum of the lesion control and rAAV5-GFP groups, whereas it was normalized by the gene transfer intervention in the TH + GCH1 treatment group (Fig. $3 g$ ). Because the in vivo $K_{d}$ values may be affected by changes in accessibility to the receptor sites (denoted here as volume of reaction, $V_{r}$ ), the fresh frozen striatal samples taken from the very same animals used in the imaging studies were processed for an in vitro competitive binding assay. In this assay system, the model is reduced to three compartments, and thus the $K_{d}$ can be determined without the potential influence of the $V_{r}$ (Fig. $\left.3 b, d\right)$. The results showed that the in vitro $K_{d}$ and $B_{\max }$ measurements were highly correlated with the in vivo values, indicating that the changes observed in the apparent binding affinity in vivo $\left(K_{d} V_{r}\right)$ is entirely attributable to the change in $K_{d}$, i.e., the affinity of $\left[{ }^{11} \mathrm{C}\right]$ raclopride to bind the $\mathrm{D}_{2}$ receptors (Fig. $3 h-$ j). Together, these results supported the interpretation that (1) the partial saturation model can permit actual quantification of $\mathrm{D}_{2}$ receptor densities and affinities separately, in both normal and parkinsonian living rats, and (2) rAAV5-mediated continuous DOPA delivery resulted in restoration of a functional endogenous DA pool, which occupied the $\mathrm{D}_{2}$ receptor sites in the striatum and competitively reduced the signal from specifically bound $\left[{ }^{11} \mathrm{C}\right]$ raclopride.

In vivo $\left[{ }^{11} \mathrm{C}\right]$ raclopride binding affinity predicts $\mathrm{DA}$ synthesis and functional recovery in motor behavior after rAAV5mediated DOPA delivery

The functional consequences of the continuous DOPA delivery by the rAAV5-TH and rAAV5-GCH1 vectors were assessed by spontaneous forelimb paw placement in the cylinder test before and 12 and 39 weeks after the vector treatment. In this test paradigm, normal animals are expected to use both paws with equal frequency, whereas unilaterally DA-depleted rats display a deficit in use of the contralateral paw. In the rAAV5-GFP-injected control group, all animals had a strong bias toward using the intact paw (only $1-2$ of 20 touches were performed with the impaired 


\section{Scatchard plots for Lesioned/rAAV-GFP treated animal}

a $\left[{ }^{11} \mathrm{C}\right]$ raclopride in vivo

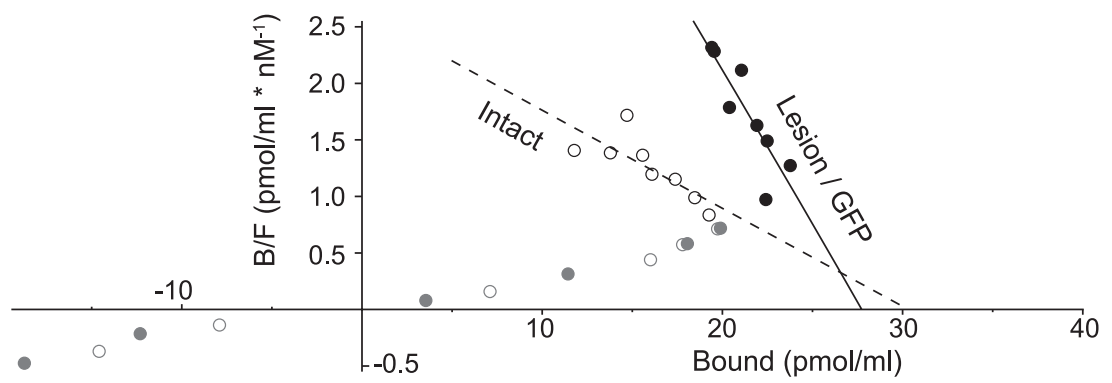

b $\left[{ }^{3} \mathrm{H}\right]$ raclopride in vitro

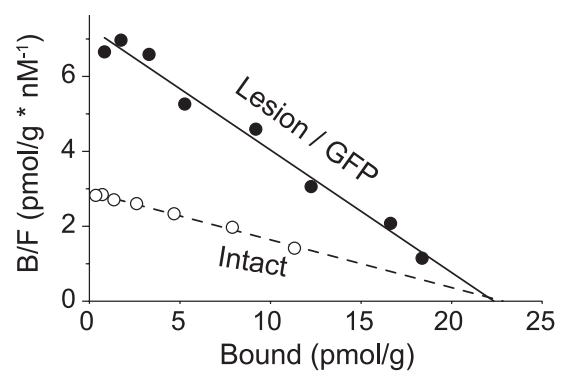

\section{Scatchard plots for Lesioned/rAAV-TH+rAAV-GCH1 treated animal}

c $\left.{ }^{111} \mathrm{C}\right]$ raclopride in vivo

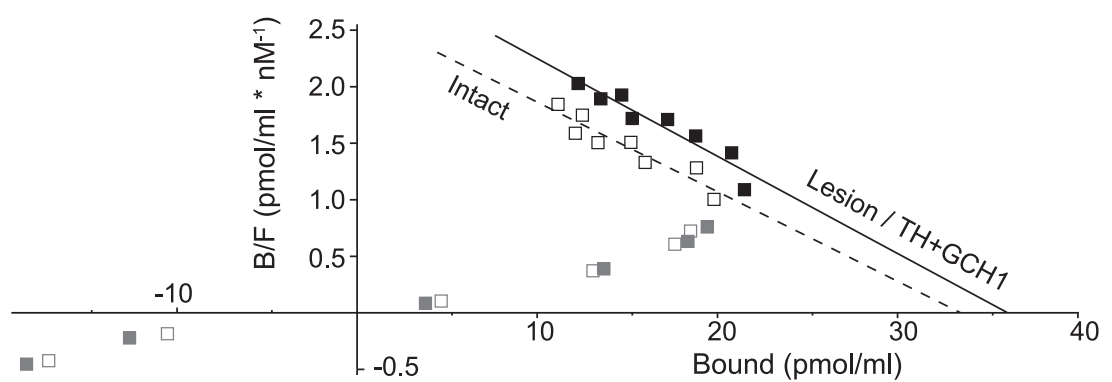

e

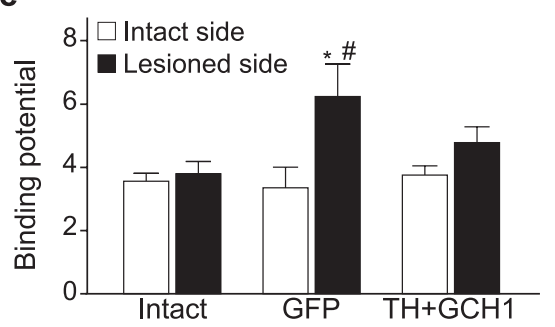

f

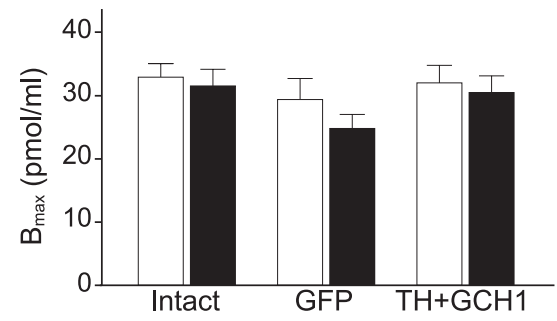

i
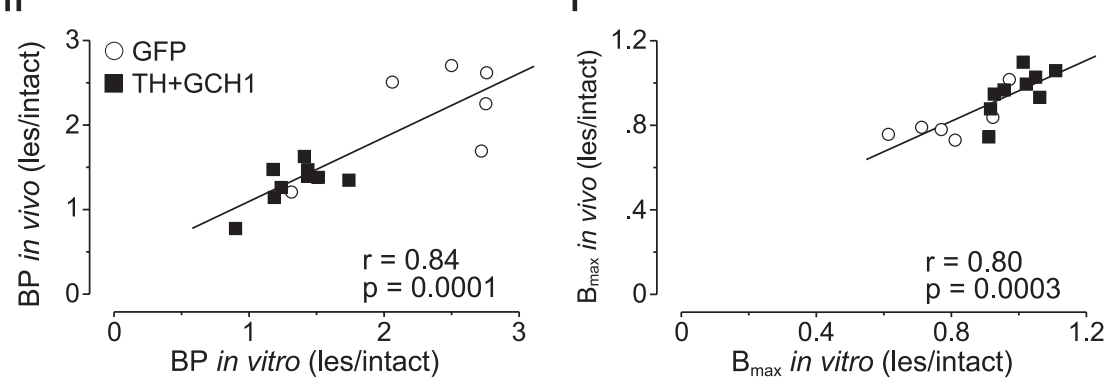

d $\left.{ }^{3} \mathrm{H}\right]$ raclopride in vitro

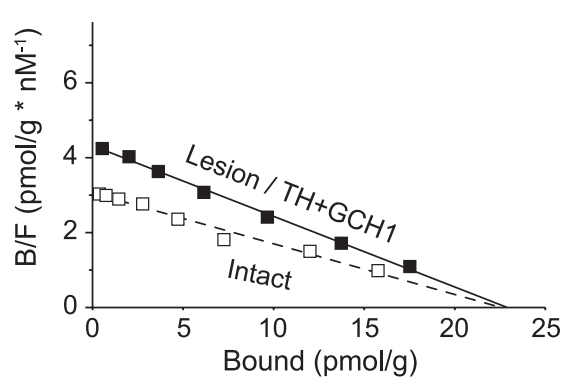

g

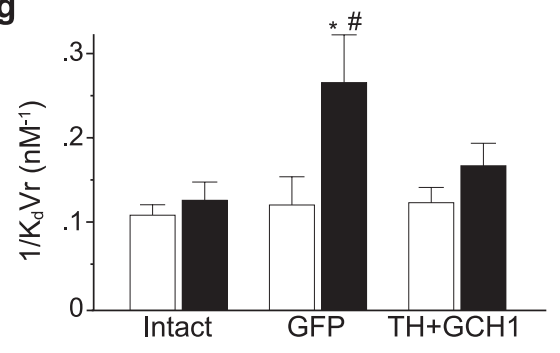

j

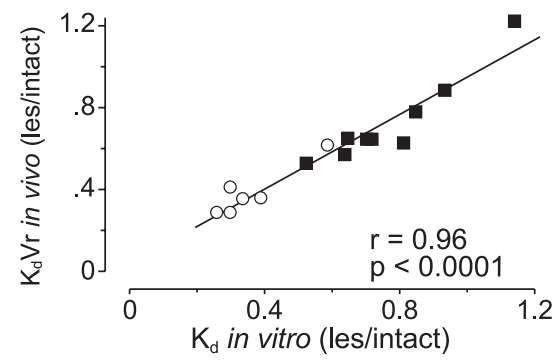

Figure 3. Quantification of the $\left[{ }^{11} \mathrm{C}\right]$ raclopride PET data. Analysis of the raclopride striatal binding was conducted by plotting the binding data in Scatchard plots both in vivo ( $\boldsymbol{a}, \boldsymbol{c}$ ) and in vitro ( $\boldsymbol{b}$, d). The data points from the lesion/GFP side clearly deviated from those on the intact side $(\boldsymbol{a}, \boldsymbol{b})$, whereas the lesion/TH + GCH1 binding mimicked the binding of the intact side $(\boldsymbol{c}, \boldsymbol{d})$. Analysis of the data from in vivo $\left[{ }^{11} \mathrm{C}\right]$ raclopride PET scans expressed as BP to the striatal $\mathrm{D}_{2}$ DA receptors indicated a significant increase on the lesion side of the GFP-injected hemiparkinsonian rats and restoration of $B P$ values to control values in the lesion side of the $\mathrm{TH}+\mathrm{GCH} 1$-injected animals $(\boldsymbol{e})$. To resolve the precise source of the change in $\mathrm{BP}$, we calculated the apparent $\mathrm{D}_{2} \mathrm{DA}$ receptor density $\left(B_{\text {max }} ; \boldsymbol{f}\right)$ and affinity of the binding to the receptors $\left(K_{d} V_{r}-\right.$ apparent in vivo $\left.K_{d i} ; \boldsymbol{g}\right)$ by calculating the $x$-intercept and slope of the best-fit line from the quantitative PET dataset at the equilibrium state (12-50 min after injection; black symbols) and found that the changes were essentially attributable to a decrease in the $K_{d} V_{r}$ and not an increase of the $B_{\max }$ values. The in vivo estimates of $B P$, $B_{\text {max }}$ and $K_{d} V_{r}$ were tightly correlated to the corresponding in vitro values from the same animals $(\boldsymbol{h}-\boldsymbol{j})$. Statistics in $\boldsymbol{e}$ : two-way ANOVA, $\chi_{(5,51)}^{2}=18.88, p<0.005 ; \boldsymbol{g}$ : two-way ANOVA, $\chi^{2}{ }_{(5,51)}$ $=18.70, p<0.005$. The two-way analysis was followed by individual contrasts with Bonferroni's correction in both tests. Regression line fits in $\boldsymbol{h}$-j are two-tailed significance of the Pearson's product-moment correlation coefficient. * indicates different from intact side; \# indicates different from normal control.

paw), whereas the rAAV5-TH + rAAV5-GCH1-treated rats showed a significant and near complete recovery at 12 weeks after vector injection, which was maintained until the end of the experiment at 39 weeks after vector administration (Fig. $4 a$ ). Moreover, the recovery seen in the cylinder test was highly correlated with the ratio of $K_{d} V_{r}$ values obtained in the lesion and intact sides in the same animals $(r=0.78 ; p=0.0006)$ (Fig. $4 b)$. Only a weak correlation was seen between the $B_{\max }$ values and cylinder test results $(r=0.53 ; p=0.042)$ (data not shown). The correlation between $K_{d} V_{r}$ values and apomorphine-induced rotational 
behavior (direct $\mathrm{D}_{1} / \mathrm{D}_{2}$ agonist) was more prominent compared with the indirect DA agonist amphetamine $(r=-0.60, p=$ 0.018 ; and $r=-0.53, p=0.040$, respectively) (Fig. $4 c-f$ ).

The 6-OHDA injection into the MFB resulted in a complete DA denervation with a $>99.8 \%$ reduction of striatal DA levels $(0.14 \pm 0.04 \mathrm{pmol} / \mathrm{mg}$ compared with $76.3 \pm 2.5 \mathrm{pmol} / \mathrm{mg}$ ) (Fig. $5 a$ ), $99.3 \%$ reduction in striatal 3,4-dihydroxyphenylacetic acid (DOPAC) levels $(0.08 \pm 0.01 \mathrm{pmol} / \mathrm{mg}$ compared with $10.69 \pm 0.71 \mathrm{pmol} / \mathrm{mg}$ ) (Fig. $5 b$ ), and $96.7 \%$ reduction in striatal homovanillic acid (HVA) levels $(0.11 \pm 0.04$ $\mathrm{pmol} / \mathrm{mg}$ compared with $3.43 \pm 0.25 \mathrm{pmol} /$ mg) (Fig. 5c) as measured in the rAAV5GFP group. Possibly, because of the lack of storage for the newly synthesized DA in the transduced striatum, the levels of DOPAC and HVA (Fig. 5b,c) were restored closer to normal values than striatal DA levels (Fig. $5 a)$. Nevertheless, the DA content in the rAAV5-TH + rAAV5-GCH1-transduced striatum $(9.4 \pm 3.9 \mathrm{pmol} / \mathrm{mg})$ reached $\sim 12 \%$ of intact side values and correlated strongly to the normalization of $K_{d} V_{r}$ in vivo and $K_{d}$ in vitro $(r=0.80, p<0.001$; and $r=$ $0.87, p<0001$, respectively) (Fig. $5 d, e$ ). Interestingly, although the binding affinity is a component of the BP, the BP measurement itself did not correlate with the DA synthesis $(r=0.41, p=0.12$, in vivo; and $r=0.30, p=$ 0.28 , in vitro; data not shown).

\section{Discussion}

The present study was designed to provide evidence that a functional endogenous DA pool can be reinstituted by viral-mediated continuous DOPA delivery in the rat parkinsonian model. For this purpose, rAAV5 vectors encoding the $\mathrm{TH}$ and $\mathrm{GCH} 1$ genes were coexpressed in the striatum of rats with a unilateral 6-OHDA lesion of the nigrostriatal projection neurons providing DA input to the striatum. We showed that $\mathrm{TH}+\mathrm{GCH} 1$ gene transfer reconstitutes the DOPA synthesis capacity in the denervated striatum, and this leads to recovery of motor functions in the treated animals. The demonstration of the presence of DA at the striatal $\mathrm{D}_{2}$ receptor sites was achieved with the $\left[{ }^{11} \mathrm{C}\right]$ raclopride tracer and microPET imaging in vivo.

Our data showed an increased BP in both the lesion control group and rAAV5GFP-injected animals. However, the changes in the BP values cannot be unequivocally interpreted. This is attributable to the fact that the $\mathrm{BP}$ values are determined by two specific properties of $\mathrm{D}_{2}$ receptors: the apparent binding affinity of $\left[{ }^{11} \mathrm{C}\right]$ raclopride to the receptor and the total receptor density in the striatum. Here we have used a partial saturation single PET experiment to determine separately both the apparent

\section{Cylinder test}
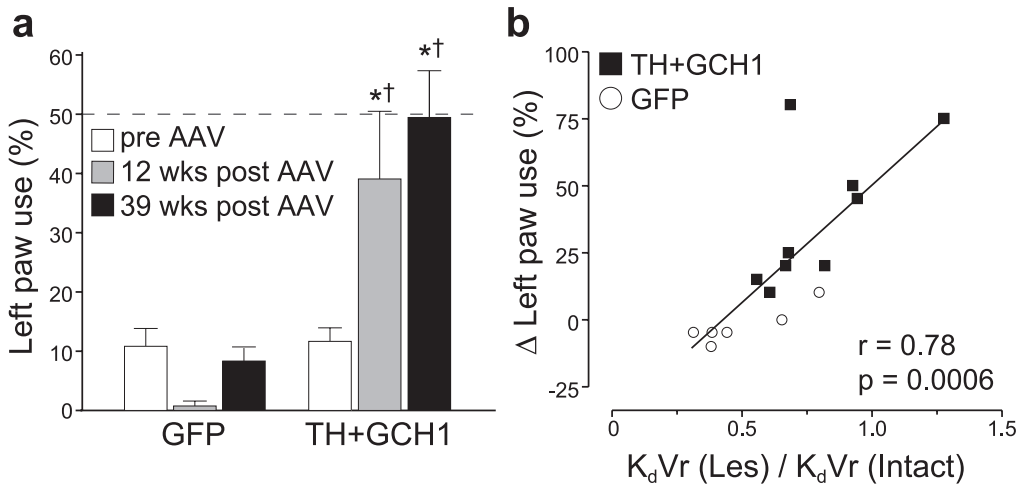

Amphetamine rotation
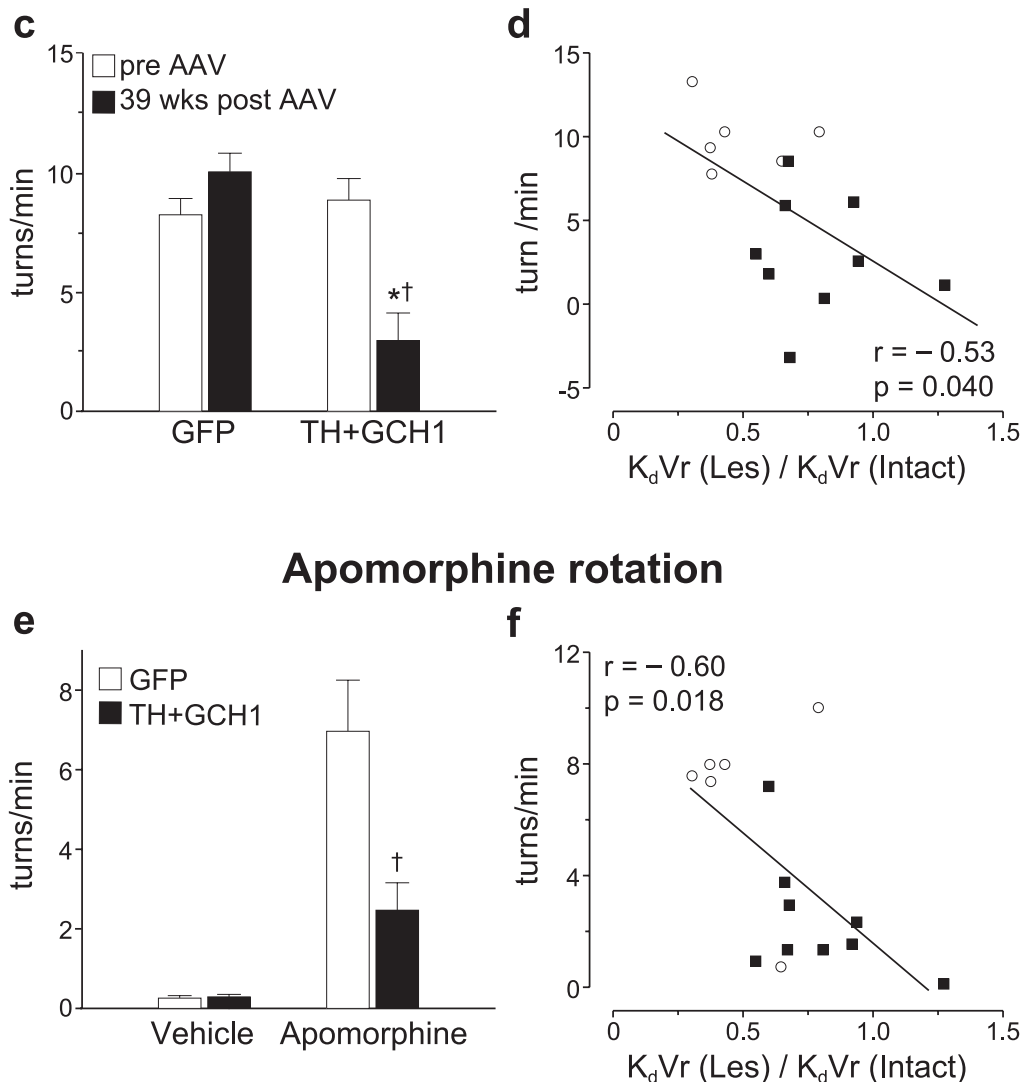

Figure 4. Correlation between the in vivo PET data and the motor behavioral performance. The animals were tested on spontaneous motor behaviors using the cylinder test $(\boldsymbol{a})$, amphetamine $(\boldsymbol{c})$, and apomorphine $(\boldsymbol{e})$ induced rotations. The use of the affected paw (left side) in the cylinder test was severely impaired after lesion. This impairment was maintained in rAAV5-GFPinjected animals, whereas the treatment group showed a significant recovery of function $(\boldsymbol{a})$. The improvement in the cylinder test, expressed as difference between the pre-vector and post-vector injection time points, was highly correlated with the $K_{d} V_{r}$ values derived from the striatal PET data $(\boldsymbol{b})$. The correlations between drug-induced rotation and $K_{d} V_{r}$ values were weaker $(\boldsymbol{d}, \boldsymbol{f})$. Statistics in $\boldsymbol{a}$ : two-way ANOVA, $\chi_{(5,44)}^{2}=31.68, p<0.001 ; \boldsymbol{c}$, two-way ANOVA, $\chi_{(3,29)}^{2}=23.65, p<0.001$; $\boldsymbol{e}$, two-way ANOVA, $\chi_{(3,29)}^{2}=35.60, p<0.001$. All two-way analysis was followed by individual contrasts with Bonferroni's correction. Regression line fits in $\boldsymbol{b}, \boldsymbol{d}$, and $\boldsymbol{f}$ are two-tailed significance of the Pearson's product-moment correlation coefficient. ${ }^{*}$ indicates different from pre-transduction score; $†$ indicates different from lesion/GFP.

affinity of the specific binding and the apparent total density of $\mathrm{D}_{2}$ receptors in the striatum. We found that lesioning the DA system resulted in an increase in the binding affinity without changing the density of $\mathrm{D}_{2}$ receptors accessible for $\left[{ }^{11} \mathrm{C}\right]$ raclopride binding. From a pharmacological point of view, anticipating that lesioning the presynaptic element of the striatal dopami- 
a

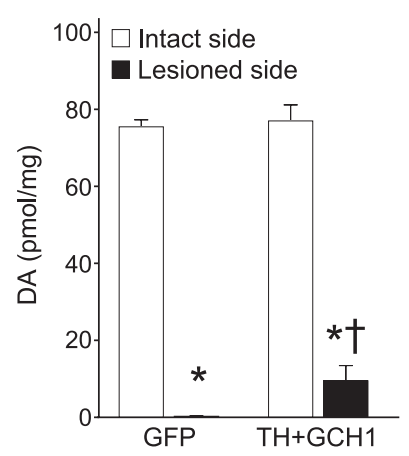

b
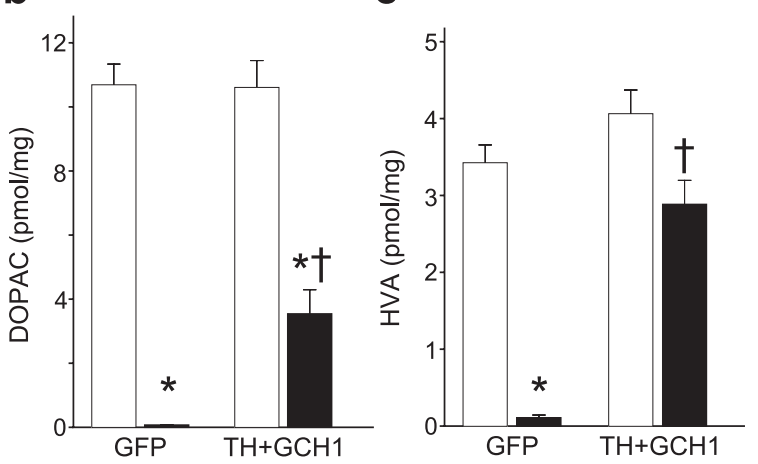

d

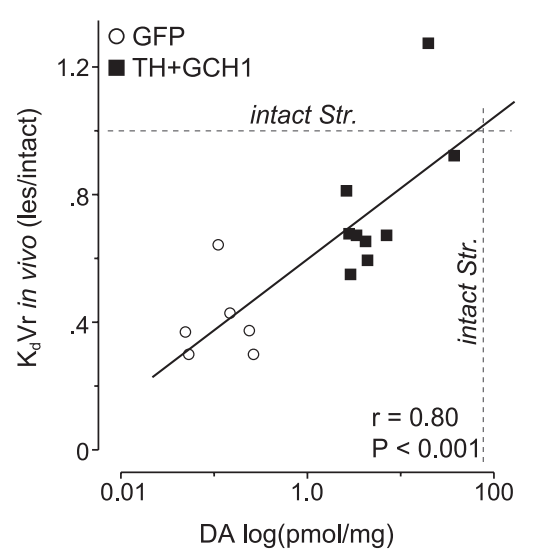

e

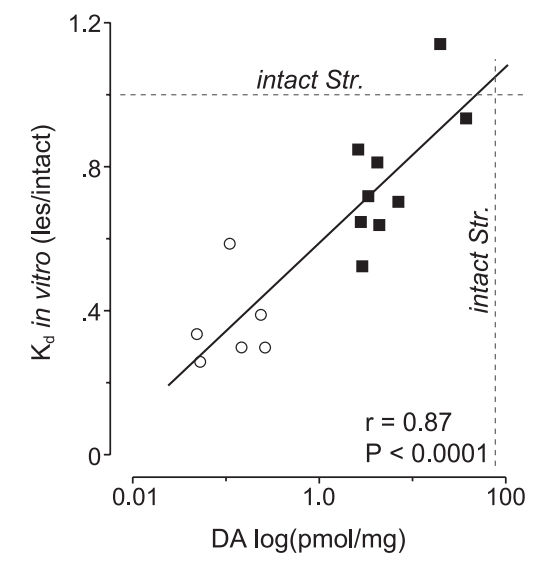

Figure 5. Tissue DA, DOPAC, and HVA levels were determined by HPLC $(\boldsymbol{a}-\boldsymbol{c})$. There was a significant restoration of all three metabolites in the rAAV5-TH + rAAV5-GCH1-treated rats. The tissue DA levels were well correlated with both in vivo $K_{d} V_{r}(\boldsymbol{d})$ and in vitro $K_{d}(\boldsymbol{e})$ values. Kruskal-Wallis nonparametric test, $\chi_{(3,29)}^{2}=24.52(\mathrm{DA}), \chi_{(3,29)}^{2}=23.19(\mathrm{DOPAC})$, and $\chi_{(3,29)}^{2}=17.56$ (HVA), $p<0.001$ for all comparisons, followed by post hoc comparisons using Mann-Whitney U test with Bonferroni's correction. * indicates different from intact side; † indicates different from lesion/GFP.

nergic synapse could affect more severely the apparent affinity than the apparent density of striatal $\mathrm{D}_{2}$ receptors can be expected as a direct consequence of a loss of dopamine (removal of a competitive inhibitor). Whether the profound removal of dopamine observed in our parkinsonian rats (average striatal dopamine concentrations in the GFP-treated lesioned animals below $1 \%$ of normal control) could also produce a concomitant upregulation of $\mathrm{D}_{2}$ postsynaptic receptors, primarily described in the literature acutely after DA lesion, was still an open question and the reason why we not only needed to quantify separately $\mathrm{D}_{2}$ receptor density and affinity in vivo but also confirm this in vitro. Indeed, we have now found in vivo by PET and also confirmed in vitro in the very same animals that the changes in $\left[{ }^{11} \mathrm{C}\right]$ raclopride observed in our experimental conditions are explained by a change in the apparent affinity and not by a change in $\mathrm{D}_{2}$ receptor density. The discrepancy between these findings and some previously published data reporting alterations of the receptor density with no change in affinity after long-term dopaminergic striatal deafferentation in 1-methyl-4-phenyl-1,2,3,6-tetrahydropyridinetreated monkeys (Doudet et al., 2002) are unclear but are likely attributable to combination of differences in lesioning conditions, time after lesion, severity of striatal dopamine loss, and possibly animal model.

Our in vivo and in vitro results unequivocally support the argument that the increase in $\left[{ }^{11} \mathrm{C}\right]$ raclopride binding in the chronically DA-depleted rat is attributed primarily to a reduced competition with endogenous extracellular DA for binding to the $\mathrm{D}_{2}$ receptors rather than a change in total number of receptors. As a corollary to this, normalization of $\left[{ }^{11} \mathrm{C}\right]$ raclopride binding in the treated rats could be most readily explained by availability of DA generated from ectopic DOPA synthesis via the human transgenic $\mathrm{TH}$ and $\mathrm{GCH} 1$ enzymes. Indeed, we found that the $K_{d}$ is the best predictor of the DA levels after rAAVmediated enzyme replacement in the parkinsonian brain. These data add significant value over the commonly used measurement of BP that did not correlate with the efficacy of the treatment in this model. Most importantly, the ratio of the binding affinity in the lesion and intact sides were highly correlated with the spontaneous behavioral test results providing an excellent readout for the functional impact of this gene therapy approach.

The state of striatal $\mathrm{D}_{2}$ receptors after lesions of the ascending dopamine system is still conflicting; some studies reported an increase above normal, whereas others suggested no change. Discrepancies between studies are likely to be attributable to the duration of the lesion, because increases in the $\mathrm{D}_{2}$ receptor levels seem to be prominent mainly acutely (2-4 weeks) after DA denervation (Savasta et al., 1987; Verhoeff et al., 2002; Xu et al., 2005) but not in chronically lesioned animals (Decamp et al., 1999). Second, when changes were detected, they were most obvious in the dorsolateral sector of the striatum, whereas medial and ventral sectors were either modified to a lesser extent or remained unchanged (Graham et al., 1990; Chritin et al., 1992). In the present experiment, analysis in chronically DA-depleted rats (6-9 months after lesion), both the in vivo and the in vitro measurements suggested no change in the total receptors accessible to raclopride when the whole striatum was assayed. Although the DA receptors are known to alternate between high- and low-affinity states based on the availability of the endogenous ligand, such changes are unlikely to affect the measurements obtained here as the binding affinity of raclopride is not modulated by the state changes in the $\mathrm{D}_{2}$ receptors (Seeman et al., 2005; Seneca et al., 2006).

Our results are in agreement with previous reports conducted in reserpine-treated animals repeatedly administered with cocaine, in which alterations of the in vivo binding for both $\mathrm{D}_{1}$ and $\mathrm{D}_{2}$ receptors were attributable to apparent modifications of the affinity and not the number of binding sites (Tsukada et al., 1996; Ginovart et al., 1997). An acute challenge with amphetamine, conversely, appears to result in a different type of response that might be mediated by changes in receptors available for ligand binding (Sun et al., 2003; Chefer et al., 2008). In the current experiments, we describe a $50 \%$ change in $K_{d} V_{r}$ after full striatal dopaminergic deafferentation. Such a drastic modification of $\mathrm{D}_{2}$ receptor affinity $(42-53 \%)$ has already been described by others using various $\mathrm{D}_{2}$ receptor radiotracers, including $\left[{ }^{11} \mathrm{C}\right]$ raclopride and FLB457 [(S)-N-[(1-ethyl-2-pyrrolidinyl)methyl]-5- 
bromo-2,3-dimethoxtbenzamide], after experimentally induced dopamine depletion (acute reserpine treatment). Fisher et al. (1995) suggested that the average DA concentration in the synaptic cleft could be $\sim 0.5 \mu \mathrm{M}$. This means that a $50 \%$ change in $\mathrm{D}_{2}$ receptor affinity observed in the dopamine-depleted rats would imply that $\sim 80 \%$ of the $D_{2}$ receptors would be occupied in the intact rat striatum.

Today, oral L-DOPA medication is the most effective and widely used pharmacotherapy for patients suffering from PD. Although the initial response to this medication may be excellent, with advancing disease, most patients develop unwanted side effects of the treatment (Marsden and Parkes, 1976; Mouradian et al., 1988; Obeso et al., 2000). These side effects are thought to be attributable to the pulsatile nature of the administration, and, in fact, several studies have reported improvements in clinical responses when patients with motor complications are treated with continuous infusion of L-DOPA or DA receptor agonists (Nutt et al., 2000; Olanow et al., 2006). However, continuous systemic pharmacotherapy is associated with an increase in frequency of other adverse effects such as hallucinations and psychosis and is often complicated because of the use of external pumps to deliver the drugs either subcutaneously or via a gastric or duodenal route. Therefore, development of a DOPA delivery restricted to areas of the brain in which the DA system is most severely affected offers a possibility to overcome these limitations and provide a more effective treatment for PD patients. This requirement can easily be met by in vivo viral gene transfer techniques, and, because of their safety profile, rAAV vectors are very suitable for such clinical applications of gene therapy in the CNS (Kaplitt et al., 2007; Stoessl, 2007; Eberling et al., 2008; Marks et al., 2008).

We showed previously that rAAV-mediated expression of the $\mathrm{TH}$ and GCH1 genes in the striatum can provide a continuous and long-term DOPA production (Mandel et al., 1998). When DOPA synthesis levels exceed a minimum threshold, this treatment yields long-lasting functional benefits in parkinsonian rats (Kirik et al., 2002). Moreover, stabilization of the striatal DOPA levels leads to alleviation of dyskinetic side effects induced by oral L-DOPA pharmacotherapy (Carlsson et al., 2005). Together, these data suggest that rAAV-mediated targeted DOPA delivery is not only a powerful tool for experimental studies but also a viable strategy for clinical application, which may overcome unresolved medication-induced complications in PD patients and provide them a better life quality.

In addition to the demonstration that normal striatal $\mathrm{D}_{2}$ receptor function is restored by rAAV-mediated DOPA delivery, the present $\left[{ }^{11} \mathrm{C}\right]$ raclopride PET imaging protocol can serve as a non-invasive method to follow $\mathrm{TH}+\mathrm{GCH}$ gene expression in humans. It could provide an additional objective measure to a potential clinical trial using rAAV vectors to deliver DOPA to PD patients because the $\left[{ }^{11} \mathrm{C}\right]$ raclopride PET imaging technique is already applicable in humans and has been demonstrated to be useful in the assessment of PD patients (Antonini et al., 1997; Piccini et al., 2003; de la Fuente-Fernandez et al., 2004).

\section{References}

Antonini A, Leenders KL, Vontobel P, Maguire RP, Missimer J, Psylla M, Günther I (1997) Complementary PET studies of striatal neuronal function in the differential diagnosis between multiple system atrophy and Parkinson's disease. Brain 120:2187-2195.

Carlsson T, Winkler C, Burger C, Muzyczka N, Mandel RJ, Cenci A, Björklund A, Kirik D (2005) Reversal of dyskinesias in an animal model of Parkinson's disease by continuous L-DOPA delivery using rAAV vectors. Brain 128:559-569.

Carlsson T, Björklund T, Kirik D (2007) Restoration of the striatal dopa- mine synthesis for Parkinson's disease: viral vector-mediated enzyme replacement strategy. Curr Gene Ther 7:109-120.

Chefer SI, Kimes AS, Matochik JA, Horti AG, Kurian V, Shumway D, Domino EF, London ED, Mukhin AG (2008) Estimation of D2-like receptor occupancy by dopamine in the putamen of hemiparkinsonian monkeys. Neuropsychopharmacology 33:270-278.

Chritin M, Savasta M, Mennicken F, Bal A, Abrous DN, Le Moal M, Feuerstein C, Herman JP (1992) Intrastriatal dopamine-rich implants reverse the increase of dopamine D2 receptor mRNA levels caused by lesion of the nigrostriatal pathway: a quantitative in situ hybridization study. Eur J Neurosci 4:663-672.

Cotzias GC, Van Woert MH, Schiffer LM (1967) Aromatic amino acids and modification of parkinsonism. N Engl J Med 276:374-379.

Decamp E, Wade T, Schneider JS (1999) Differential regulation of striatal dopamine $\mathrm{D}(1)$ and $\mathrm{D}(2)$ receptors in acute and chronic parkinsonian monkeys. Brain Res 847:134-138.

de la Fuente-Fernández R, Sossi V, Huang Z, Furtado S, Lu JQ, Calne DB, Ruth TJ, Stoessl AJ (2004) Levodopa-induced changes in synaptic dopamine levels increase with progression of Parkinson's disease: implications for dyskinesias. Brain 127:2747-2754.

Delforge J, Syrota A, Bottlaender M, Varastet M, Loc'h C, Bendriem B, Crouzel C, Brouillet E, Maziere M (1993) Modeling analysis of [ $\left.{ }^{11} \mathrm{C}\right]$ flumazenil kinetics studied by PET: application to a critical study of the equilibrium approaches. J Cereb Blood Flow Metab 13:454-468.

Delforge J, Pappata S, Millet P, Samson Y, Bendriem B, Jobert A, Crouzel C, Syrota A (1995) Quantification of benzodiazepine receptors in human brain using PET, $\left[{ }^{11} \mathrm{C}\right]$ flumazenil, and a single-experiment protocol. J Cereb Blood Flow Metab 15:284-300.

Dorsey ER, Constantinescu R, Thompson JP, Biglan KM, Holloway RG, Kieburtz K, Marshall FJ, Ravina BM, Schifitto G, Siderowf A, Tanner CM (2007) Projected number of people with Parkinson disease in the most populous nations, 2005 through 2030. Neurology 68:384-386.

Doudet DJ, Jivan S, Ruth TJ, Holden JE (2002) Density and affinity of the dopamine D2 receptors in aged symptomatic and asymptomatic MPTPtreated monkeys: PET studies with [11C] raclopride. Synapse 44:198-202.

Eberling JL, Jagust WJ, Christine CW, Starr P, Larson P, Bankiewicz KS, Aminoff MJ (2008) Results from a phase I safety trial of hAADC gene therapy for Parkinson disease. Neurology 70:1980-1983.

Farde L, Ehrin E, Eriksson L, Greitz T, Hall H, Hedström CG, Litton JE, Sedvall G (1985) Substituted benzamides as ligands for visualization of dopamine receptor binding in the human brain by positron emission tomography. Proc Natl Acad Sci U S A 82:3863-3867.

Fearnley JM, Lees AJ (1991) Ageing and Parkinson's disease: substantia nigra regional selectivity. Brain 114:2283-2301.

Fisher RE, Morris ED, Alpert NM, Fischman AJ (1995) In vivo imaging of neuromodulatory synaptic transmission using PET: a review of relevant neurophysiology. Hum Brain Mapp 3:24-34.

Ginovart N, Farde L, Halldin C, Swahn CG (1997) Effect of reserpineinduced depletion of synaptic dopamine on $\left[{ }^{11} \mathrm{C}\right]$ raclopride binding to D2-dopamine receptors in the monkey brain. Synapse 25:321-325.

Graham WC, Crossman AR, Woodruff GN (1990) Autoradiographic studies in animal models of hemi-parkinsonism reveal dopamine D2 but not D1 receptor supersensitivity. I. 6-OHDA lesions of ascending mesencephalic dopaminergic pathways in the rat. Brain Res 514:93-102.

Grimm D, Kay MA, Kleinschmidt JA (2003) Helper virus-free, optically controllable, and two-plasmid-based production of adeno-associated virus vectors of serotypes 1 to 6. Mol Ther 7:839-850.

Kaplitt MG, Feigin A, Tang C, Fitzsimons HL, Mattis P, Lawlor PA, Bland RJ, Young D, Strybing K, Eidelberg D, During MJ (2007) Safety and tolerability of gene therapy with an adeno-associated virus (AAV) borne GAD gene for Parkinson's disease: an open label, phase I trial. Lancet 369:2097-2105.

Kirik D, Rosenblad C, Bjorklund A, Mandel RJ (2000) Long-term rAAVmediated gene transfer of GDNF in the rat Parkinson's model: intrastriatal but not intranigral transduction promotes functional regeneration in the lesioned nigrostriatal system. J Neurosci 20:4686-4700.

Kirik D, Georgievska B, Burger C, Winkler C, Muzyczka N, Mandel RJ, Bjorklund A (2002) Reversal of motor impairments in parkinsonian rats by continuous intrastriatal delivery of L-dopa using rAAV-mediated gene transfer. Proc Natl Acad Sci U S A 99:4708-4713.

Kish SJ, Shannak K, Hornykiewicz O (1988) Uneven pattern of dopamine 
loss in the striatum of patients with idiopathic Parkinson's disease. Pathophysiologic and clinical implications. N Engl J Med 318:876-880.

Kurlan R, Rubin AJ, Miller C, Rivera-Calimlim L, Clarke A, Shoulson I (1986) Duodenal delivery of levodopa for on-off fluctuations in parkinsonism: preliminary observations. Ann Neurol 20:262-265.

Langer O, Någren K, Dollé F, Lundkvist C, Sandell J, Swahn CG, Vaufrey F, Crouzel C, Mazière B, Halldin C (1999) Precursor synthesis and radiolabelling of the dopamine D2 receptor ligand [11C]raclopride from [11C]methyl triflate. J Labeled Comp Radiopharm 42:1183-1193.

Lee T, Seeman P, Rajput A, Farley IJ, Hornykiewicz O (1978) Receptor basis for dopaminergic supersensitivity in Parkinson's disease. Nature 273:59-61.

Lindgren P, von Campenhausen S, Spottke E, Siebert U, Dodel R (2005) Cost of Parkinson's disease in Europe. Eur J Neurol 12 [Suppl 1]:68-73.

Mandel RJ, Rendahl KG, Spratt SK, Snyder RO, Cohen LK, Leff SE (1998) Characterization of intrastriatal recombinant adeno-associated virusmediated gene transfer of human tyrosine hydroxylase and human GTPcyclohydrolase I in a rat model of Parkinson's disease. J Neurosci 18:4271-4284.

Marks WJ Jr, Ostrem JL, Verhagen L, Starr PA, Larson PS, Bakay RA, Taylor R, Cahn-Weiner DA, Stoessl AJ, Olanow CW, Bartus RT (2008) Safety and tolerability of intraputaminal delivery of CERE-120 (adenoassociated virus serotype 2-neurturin) to patients with idiopathic Parkinson's disease: an open-label, phase I trial. Lancet Neurol 7:400-408.

Marsden CD, Parkes JD (1976) “On-off” effects in patients with Parkinson's disease on chronic levodopa therapy. Lancet 1:292-296.

Mauger G, Saba W, Hantraye P, Dolle F, Coulon C, Bramoullé Y, Chalon S, Grégoire MC (2005) Multiinjection approach for D2 receptor binding quantification in living rats using [11C]raclopride and the beta-microprobe: crossvalidation with in vitro binding data. J Cereb Blood Flow Metab 25:1517-1527.

Mouradian MM, Juncos JL, Fabbrini G, Chase TN (1987) Motor fluctuations in Parkinson's disease: pathogenetic and therapeutic studies. Ann Neurol 22:475-479.

Mouradian MM, Juncos JL, Fabbrini G, Schlegel J, Bartko JJ, Chase TN (1988) Motor fluctuations in Parkinson's disease: central pathophysiological mechanisms, Part II. Ann Neurol 24:372-378.

Nutt JG, Obeso JA, Stocchi F (2000) Continuous dopamine-receptor stimulation in advanced Parkinson's disease. Trends Neurosci 23:S109-S115.

Obeso JA, Luquin MR, Martinez-Lage JM (1986) Lisuride infusion pump: a device for the treatment of motor fluctuations in Parkinson's disease. Lancet 1:467-470.

Obeso JA, Olanow CW, Nutt JG (2000) Levodopa motor complications in Parkinson's disease. Trends Neurosci 23:S2-S7.

Olanow CW, Obeso JA, Stocchi F (2006) Continuous dopamine-receptor treatment of Parkinson's disease: scientific rationale and clinical implications. Lancet Neurol 5:677-687.

Paxinos G, Watson C (1986) The rat brain in stereotaxic coordinates, Ed 2. San Diego: Academic.

Piccini P, Pavese N, Brooks DJ (2003) Endogenous dopamine release after pharmacological challenges in Parkinson's disease. Ann Neurol 53:647-653.

Quinn N, Parkes JD, Marsden CD (1984) Control of on/off phenomenon by continuous intravenous infusion of levodopa. Neurology 34:1131-1136.

Savasta M, Dubois A, Feuerstein C, Manier M, Scatton B (1987) Denervation supersensitivity of striatal D2 dopamine receptors is restricted to the ventro- and dorsolateral regions of the striatum. Neurosci Lett $74: 180-186$.

Schallert T, Fleming SM, Leasure JL, Tillerson JL, Bland ST (2000) CNS plasticity and assessment of forelimb sensorimotor outcome in unilateral rat models of stroke, cortical ablation, parkinsonism and spinal cord injury. Neuropharmacology 39:777-787.

Seeman P, Guan HC, Civelli O, Van Tol HH, Sunahara RK, Niznik HB (1992) The cloned dopamine D2 receptor reveals different densities for dopamine receptor antagonist ligands. Implications for human brain positron emission tomography. Eur J Pharmacol 227:139-146.

Seeman P, Weinshenker D, Quirion R, Srivastava LK, Bhardwaj SK, Grandy DK, Premont RT, Sotnikova TD, Boksa P, El-Ghundi M, O’Dowd BF, George SR, Perreault ML, Männistö PT, Robinson S, Palmiter RD, Tallerico T (2005) Dopamine supersensitivity correlates with D2High states, implying many paths to psychosis. Proc Natl Acad Sci U S A 102:3513-3518.

Seneca N, Finnema SJ, Farde L, Gulyás B, Wikström HV, Halldin C, Innis RB (2006) Effect of amphetamine on dopamine D2 receptor binding in nonhuman primate brain: a comparison of the agonist radioligand [11C]MNPA and antagonist [11C] raclopride. Synapse 59:260-269.

Stoessl AJ (2007) Gene therapy for Parkinson's disease: early data. Lancet 369:2056-2058.

Sun W, Ginovart N, Ko F, Seeman P, Kapur S (2003) In vivo evidence for dopamine-mediated internalization of $\mathrm{D} 2$-receptors after amphetamine: differential findings with $\left[{ }^{3} \mathrm{H}\right]$ raclopride versus $\left[{ }^{3} \mathrm{H}\right]$ spiperone. Mol Pharmacol 63:456-462.

Tanner CM, Goldman SM (1996) Epidemiology of Parkinson's disease. Neurol Clin 14:317-335.

Tsukada H, Kreuter J, Maggos CE, Unterwald EM, Kakiuchi T, Nishiyama S, Futatsubashi M, Kreek MJ (1996) Effects of binge pattern cocaine administration on dopamine $\mathrm{D}_{1}$ and $\mathrm{D}_{2}$ receptors in the rat brain: an in vivo study using positron emission tomography. J Neurosci 16:7670-7677.

Verhoeff NP, Hussey D, Lee M, Tauscher J, Papatheodorou G, Wilson AA, Houle S, Kapur S (2002) Dopamine depletion results in increased neostriatal $\mathrm{D}(2)$, but not $\mathrm{D}(1)$, receptor binding in humans. Mol Psychiatry 7:233-238.

Xu L, Daly T, Gao C, Flotte TR, Song S, Byrne BJ, Sands MS, Parker Ponder K (2001) CMV-beta-actin promoter directs higher expression from an adeno-associated viral vector in the liver than the cytomegalovirus or elongation factor 1 alpha promoter and results in therapeutic levels of human factor $\mathrm{X}$ in mice. Hum Gene Ther 12:563-573.

Xu ZC, Ling G, Sahr RN, Neal-Beliveau BS (2005) Asymmetrical changes of dopamine receptors in the striatum after unilateral dopamine depletion. Brain Res 1038:163-170. 